carried out on Black Rock on Dale beach. Ballantine ${ }^{2}$ rated the shore as "very sheltered". The experiment began on July 3,1968 , and continued until July 8. The limpets' shells and the adjacent rocks were marked with vertical lines of paint to indicate the "home" positions of the animals.

The positions of the animals were noted in relation to their home site at different times of day and at different states of the tide. To do this, diving had to be done at high tide. All the limpets returned to their original homing site after moving. During the experiment the weather was fine with some sunshine and the sea was calm with little or no swell. The results are summarized in Table 1.

Table 1. Movement of Patella vulgata in RELATION to TIME AND to tidaL

\begin{tabular}{|c|c|c|c|c|}
\hline \multicolumn{5}{|c|}{ STATE } \\
\hline Time & $\begin{array}{l}\text { Position of limpet } \\
\text { in relation to } \\
\text { tide }\end{array}$ & $\begin{array}{c}\text { Total } \\
\text { No. of } \\
\text { observations }\end{array}$ & $\begin{array}{l}\text { Total No. } \\
\text { observed } \\
\text { moving }\end{array}$ & $\begin{array}{c}\text { Approximate } \\
\text { percentage of } \\
\text { limpets moving }\end{array}$ \\
\hline Day & Exposed & 54 & 9 & $16 \cdot 7$ \\
\hline $\begin{array}{l}\text { Day } \\
\text { Night }\end{array}$ & $\begin{array}{l}\text { Covered } \\
\text { Exposed }\end{array}$ & 54 & 26 & $48 \cdot 1$ \\
\hline
\end{tabular}

The table shows that an appreciably higher percentage of animals moved when they were exposed during the day. The greatest movements occurred in the second half of the animals' period of exposure (that is in the period between the time of low tide and the limpets subsequently being covered). All limpets had returned to their home site before the incoming tide reached them.

R. Dearnaley

C. B. DEI, MaR

M. J. PARR

E. J. Pophan

Department of Biology,

University of Salford.

Reccived December 16, 1968.

1 Yonge, C. M., The Sea Shore (Collins, London, 1949).

${ }^{2}$ Ballantine, W. J., Field Studies, 1 (3), 1 (1961).

\section{Aflatoxin produced by 1,626 Isolates of Aspergillus flavus from Groundnut Kernels and Soils in Israel}

AGRIcultural products are often poisoned by Aspergillus flavus. Aflatoxins produced by a few strains (isolates) of A. flavus are thought to be primarily responsible for the toxic activity of that fungus on animals ${ }^{1,2}$ and plants ${ }^{3-5}$. Many agricultural products have been tested as substrates for producing aflatoxin by that fungus. The amount and composition of aflatoxin formed vary with the substrate, environmental conditions and mould strain $^{6, ?}$.

We have tested a large population of $A$. flavus for their potential to produce aflatoxin, including the qualitative composition of the aflatoxins produced and their quantitative yicld.

Spores were sown in Erlenmeyer flasks on $10 \mathrm{~g}$ of wheat, wetted previously with $25 \mathrm{ml}$. of tap water in the qualitative experiments, and with $10 \mathrm{ml}$. in the quantitative experiments. Incubation lasted 8 days at $24^{\circ} \mathrm{C}$. In the qualitative tests it was terminated by heating the culture at $100^{\circ} \mathrm{C}$ for $30 \mathrm{~min}$ in an autoclave.

Extraction was carried out according to a method described by Campbell et al. ${ }^{8}$. The extracts were tested by thin-layer chromatography (TLC) and the type of aflatoxin present $\left(B_{1}, B_{2}, G_{1}, G_{2}\right)$ was determined. In the quantitative tests the culture was killed by covering it with chloroform and heating to $70^{\circ} \mathrm{C}$ for $10 \mathrm{~min}$. Extraction and determination of aflatoxins were carried out according to Pons et al..$^{9}$, except that $(a)$ chloroform : acetone mixture (85:15) was used as developing solvent

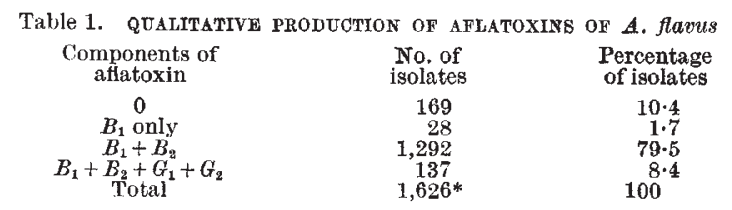

* Of the isolates, 845 were from kernels and 542 from soil of groundnut fields. The toxicity was the same in both; more or less 90 per cent were toxic. Table 2. Concentration of aflatoxin $B_{1}$ Produced BY Isolates of

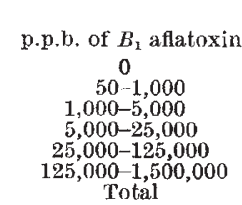
A. flavus

$\begin{array}{cc}\text { No. of } & \begin{array}{c}\text { Percentage } \\ \text { of isolates }\end{array} \\ \text { isolates } & 1 \cdot 3 \\ 10 & 5 \cdot 6 \\ 42 & 13 \cdot 7 \\ 103 & 18 \cdot 5 \\ 139 & 37 \cdot 7 \\ 282 & 23 \cdot 2 \\ 174 & 100\end{array}$

instead of chloroform : methanol (97:3)-we found this solvent gave a better separation of the common aflatoxins; (b) the development tank was not lined with filter paper.

The results in Table 1 show the composition of 1,626 isolates of $A$. flavus tested in our laboratory. Only $10 \cdot 4$ per cent of these produced no toxin, while all others contained $B_{1}$. Most of the toxic isolates also produced $B_{2}$, but only a few produced all four aflatoxins. These results were obtained during the entire research project (1963-68).

Quantitative TLC tests were performed on 750 of the 1,626 isolates in Table 1 . Some isolates produced as much as 1,500,000 p.p.b. ( $\mu$ g aflatoxin $B_{1} / \mathrm{kg}$ of substrate), while others produced 50 p.p.b. only. This emphasizes the enormous potential range of toxin production by the isolates. The results presented in Table 2 show that more than 60 per cent of the isolates produce aflatoxin in excess of 25,000 p.p.b. These results were obtained during the last 2 years of the project $(1967-68)$.

Compared with the results of other investigators $6,7,11,12$, who used only a few strains of $A$. flavus usually supplied from stocks, we have isolated a great many strains from different sources. Our isolates were derived from groundnuts and from soil of groundnut fields in various regions of Israel, but the source of the isolate had no connexion with its degree of toxicity.

The percentage of isolates not producing any aflatoxin seemed to vary during the 5 years of the study (comparo Table 1 and Table 2). If the apparent changes in the population of $A$. flavus strains during the time of the research are due to ecological factors, it would be most interesting to find out what they really are, and whether wo could induce these variations in the laboratory.

This work was supported by a grant from the US Department of Agriculture.

Department of Botany,

A. Z. JOFFE

Hebrew University,

Jerusalem, Israel.

Received December 3, 1968.

${ }^{1}$ Carnaghan, R. B. A., Hartley, R. D., and O'Kelly, J., Nature, 200, 1101 (1963).

${ }^{2}$ Peers, F. G., Trop. Sci., IX, 186 (1967).

${ }^{3}$ Schoental, R., and White, A. F., Nature, 205, 57 (1965).

4 El-Khadem, M., Phytopathol. Z., 61, 218 (1968).

${ }^{5}$ Joffe, A. Z., Plant and Soil (in the press).

- Hesseltine, C. W. Shotwell, O. C., Ellis, J. J., and Stubblefleld, R. D., Bact. Rev., 30, 795 (1966).

7 Stubblefield, R. D., Shotwell, V. L., Hegseitine, C. W., Smith, M. L., and Hall, H. H., Appl. Microbiol., 15, 186 (1967).

${ }^{8}$ Campbell, A. D., Dorsey, E., and Eppley, R. M., Otfic. Agrie. Chemists, 47, $1002(1964)$.

'Pons, W. A., Cucullu, A. F., Lee, L. S., Robertson, J. A., Franz, A. O., and Goldblatit, L. A., J. Ass. Offic. Anal. Chem., 49, 554 (1966).

${ }^{20}$ Ciegler, A., Peterson, R. E., Lagoda, A. A., and Hall, H. H., Appl. Microbiol., 14, 826 (1966).

11 Shotwell, O. L., Hesseltine, C. W., Stubblefield, R. D., and Sorenson, W. G., Appl. Microbiol., 14, 425 (1966).

12 Davis, N. D., Diener, U. L., and Eldridge, D. W., Appl. Microbiol., 14, 378 (1966). 